\title{
Use of liquid smoke for sustainable food preservation and postharvest loss and waste reduction (A review)
}

\author{
Courage Y. Krah ${ }^{1 *}$, Sutrisno ${ }^{2}$, Samsudin ${ }^{3}$, Idham S. Harahap ${ }^{4}$ \\ ${ }^{1}$ Department of Horticulture, Kwame Nkrumah University of Science and Technology(KNUST), Kumasi, Ghana \\ 1,2 Department of Mechanical and Biosystem Engineering, Institut Pertanian Bogor (IPB University), Bogor, Indonesia \\ ${ }^{3}$ Research Institute for Industrial and Beverage Crops (BALITTRI), Ministry of Agriculture, Sukabumi, Indonesia \\ ${ }^{4}$ Department of Plant Protection, Institut Pertanian Bogor (IPB University), Bogor, Indonesia
}

\section{Keywords \\ Postharvest \\ Food loss \\ Food security \\ Preservation \\ Liquid smoke}

Received: 2 April 2019

Accepted: 7 May 2019

Published: 10 June 2019

\begin{abstract}
The primary aim of every post-harvest technology is to prolong shelf life and maintain produce quality. Recent efforts to extend the shelf life of agricultural produces have culminated in the use of various methods, among which some have dangerous side effects to human health and the environment, others are just too expensive due to the high cost of production thereby making their usage unsustainable and uneconomical. Among the safe and sustainable alternatives under development, Liquid Smoke (LS) appears to have very remarkable potentials. However, the Postharvest Loss and Waste (PHLW) reduction potential of LS have been highly underrepresented in both scientific and non-scientific literature. This work, therefore, analyses and bring to light the potentials of LS for reducing postharvest losses and prolonging the shelf life of agricultural produce. The usage against insect infestation, microorganism attack, and physiological disorder of products are discussed. A careful compilation of recent literature reporting various waste materials for producing LS is also reported in this work. The active components (carbonyls, organic acids, and Phenols) responsible for its potency in reducing food loss are also discussed. Finally, a simple conceptual framework is used to illustrate the strategic and systematic role played by LS in reducing PHLW, conserving the environment, and contributing to Sustainable Development Goals (SDGs).
\end{abstract}

(C) 2019 The Author(s). Published by TAF Publishing.

\section{INTRODUCTION}

Solving the issue of Postharvest losses and waste (PHLW) is very paramount in the achievement of Sustainable Development Goals (SDGs) of the United Nations (UN). As a sign of commitment to fight this menace, target 3 of Goal 12 (goal 12.3) has been dedicated to mobilization of resources and efforts to half postharvest waste and losses globally by the end of the year 2030. This target if achieved will directly contribute to the achievement of Goal number 2 which is targeted at ending hunger and achieving food security [1]. The term food loss is defined as the reduction of eatable food which occurs throughout the part of the supply chain that supplies food specifically for human consumption [2, 3]. Furthermore, [4] in an attempt to shed light on the difference between loss and waste referred to the postharvest loss as unintended losses occurring right from the beginning of the supply chain when harvesting is done through to retail and consumption. They are often caused by technical, institutional, and legal errors in the production and supply chain systems of production. In contrast, postharvest waste is created when wholesome produce earmarked for human consumption never gets eaten, instead, it gets discarded [2]. [5] in an attempt to balance the two terms defined food waste to be a subset of the broader subject of food loss.

Loses can be either quantitative or qualitative, where quantitative losses are those often defined based on volume and weight. These two dimensions of measurement can also be expressed in monetary and energy values, and then gives rise to another derivative called economic loss. Qualita-

\footnotetext{
${ }^{*}$ Corresponding author: Courage Y. Krah

†email: couragekrah@yahoo.com
} 
tive losses, on the other hand, encompasses decays, physical damage, and unacceptable visual changes in aspects like size, shapes, and colour of produce. These visual changes are sometimes representations of nutritional losses happening within.

Agricultural products are generally classified into two distinct parts: horticultural produce and cereals grains and oils seeds. when it comes to the post-harvest storage ability of produce they are often grouped into perishable and durable products. While the horticultural crops include fruits, vegetables, root, and tubers, the cereals grains and oils seeds include nuts, most legumes, and dried beans.

Postharvest loss assessment researches have revealed that perishable food commodities account for the most food loss and generate the highest waste by weight. According to [5], postharvest loss of perishable horticultural products globally has reached a maximum of $60 \%$ for some commodities. In a worst-case scenario, [4] in their report documented as high as $80 \%$ losses for fruits and leafy green vegetables within tropical regions.

The variance in their storage behaviour can be explained by the variation in their characteristics such as moisture content, texture, physiology, etc. The table below gives details of some characteristics that distinguish perishable crops from the durables.

TABLE 1

DIFFERENCES IN CHARACTERISTICS OF HORTICULTURAL CROPS AND CEREALS AND OILSEEDS

\begin{tabular}{|c|c|}
\hline Horticultural Crops & Cereals and Oilseeds \\
\hline Moisture content is high, averagely $70 \%-95 \%$ & moisture content mostly low, $10 \%-20 \%$ \\
\hline Individual produce sizes are larger, up to $5 \mathrm{~kg}$ & Small individual sizes, often $<1 \mathrm{~g}$ \\
\hline Rate of respiration comparatively higher & Rate of respiration comparatively lower \\
\hline $\begin{array}{l}\text { Often produces heats as high as } 0.5-70 \text { megajoule/ton/day at a tem- } \\
\text { perature of } 20^{\circ} \mathrm{C}\end{array}$ & $\begin{array}{l}\text { Often produces a smaller amount of heat ( } 0.05 \text { mega- } \\
\text { joule/ton/day) }\end{array}$ \\
\hline Have soft texture hence easily gets bruised & Posses very tough texture \\
\hline Have shorter shelf life ranging from few days up to some months & Shelf life relatively stable can last up to several years. \\
\hline $\begin{array}{l}\text { Losses often result from bacteria rotting, fungi rotting, and senes- } \\
\text { cence. }\end{array}$ & $\begin{array}{l}\text { Losses often result from insects, rodents, and mould attack. } \\
\text { In some cases, sprouting and bruising }\end{array}$ \\
\hline $\begin{array}{l}\text { Losses in Less Developed Countries (LDCs) relatively higher } \\
(15 \%-50 \%)\end{array}$ & LDCs generally experience relatively lower losses $10 \%-20 \%$ \\
\hline
\end{tabular}

Source: [6]

Since the properties of the various food crops are not the same, factors that cause their postharvest their loss also vary. Generally, the factors that cause major postharvest loss of production can be categorized into the forms below.

\section{A. Biological and Microbiological}

The main agents of attack here include insects, fungus bacteria, animals, etc. Usually, the pathogens do not attack healthy or fresh products, they rather take advantage of wounds, bruises, or other deteriorations on the fruit.

\section{B. Chemical/Biochemical}

A typical example is an oxidation reaction. Pesticides and insecticides used can also influence chemical and biochemical reactions. These reactions sometimes result in both nutritional and physical losses of commodities.

\section{Mechanical}

The problem causes by this factor becomes very rampant during the harvesting period through to transportation.
The losses from mechanical damages often come in the form of breaking, cracking, punctures, shape deformations, etc.

\section{Physiological}

These factors occur as a result of the development process of the produce or the produce undertaking it natural metabolic activities such as respiration, photosynthesis, etc. These factors though not intended to harm the crop often result in losses due to alteration from the normal way. Hence, they are sometimes described as physiological disorders.

\section{E. Physical}

Inappropriate environmental and climatic conditions can be classified as physical factors that cause postharvest losses. This includes extremes of temperature, relative humidity, sunburn, wind, hail, etc [7].

[4] regrouped and simplified the previously mentioned factors and some additional ones under three names: biological, environmental, and socioeconomic. All other ancillary 
causes of postharvest losses may be partially or fully represented by one of the factors already listed.

The Biological causes of deterioration are often linked with the rate of respiration, production of ethylene, and changes in characteristics such as nutritional composition, flavour, colour, and texture. These are also known as internal factors.

The environmental factors are also known as the external factors, this included temperature, relative humidity, the velocity of air, and composition of the gas in the atmosphere. The main gases of concern include $\mathrm{O}_{2}, \mathrm{CO}_{2}$, and ethylene $\left(\mathrm{C}_{2} \mathrm{H}_{4}\right)$. The environmental factor has both a direct and indirect influence on biological factors.

The socio-economic factors are quite broad and include issues about transport and marketing systems, government policies, availability of requisite tools and equipment, and accessibility information. The magnitude and extent of the other two factors (biological and environmental) are indirectly influenced by this one (socio-economic factors).

There are some disparities in the number of food losses occurring in advanced and emerging nations. In the emerging economies, a larger portion of the postharvest losses occur between farm and the market ( $>40 \%$ ), but in advanced and developed economies, the chunk of losses $(40 \%)$ occur at the consumer levels [8].

Among the various causes of PHLW, physiological microbiological, and mechanical factors were named as the largest contributors to losses in horticultural commodities [6]. On the part of durable products like grains and legumes, biological factors in the form of insect attack is a big enemy to extended storage of most cereals, legumes, and grains. Insect infestation can cause a reduction in the quality of stored cereals, dried seeds, pulses, and legume products that are kept in humid and warm environments. Insects damage in stored cereals can result in a $5-10 \%$ loss of stored products in the temperate zones while the tropical zone could go as high as $20-30 \%$ [5]. These insects often cause quantitative losses by chewing and boring holes into the commodities while quality losses are often characterized by residues, foreign bodies, frass, dead remains, and sometimes pathogenic organism which leads to issues of food safety. Insect attack also causes a reduction in the nutritional composition of the target commodity.

The reduction of PHLW is therefore very important because it does not only make food available but also causes other positive externalities such as environmental protection, reduced food prices, better nutrition, etc. A study by [9] reveals PHLW of perishable commodities including animalbased products causes the loss of more than $60 \%$ of all mi- cronutrients except vitamin B12.

As part of the PHLW reduction strategies developed, the use of chemicals plays a vital role. Initially, the use of these chemicals appeared to be flawlessly and effective until excessive and indiscriminate usage became rampant consequently creating problems for human health and the natural atmosphere. Some researchers recorded teratogenicity, residual toxicity, carcinogenicity, prolonged degradation period, ecological pollution, exorbitant cost, and development of resistance among target pests to be associated with some of the commonly used chemicals $[10,11]$.

10 reported health risks related to ethyl chlorpyrifos, methylchlorpyrifos, and omethoate residues in tomato fruits. Dichlorvos, methyl-chlorpyrifos, monocrotophos, ethyl-chlorpyrifos, and omethoate residues were also found in eggplant. [12] likewise sampled vegetables from the market and discovered that $23 \%$ of them contained organophosphorus chemicals above their Maximum Residue Limits (MRL). Most of the chemicals for treating farm produce pose a threat to the environment [13]. There has also been a report on insect resistance to known chemical treatments that used to be effective. [14] reported resistance in strains of Lasioderma serricorne and Trogoderma granarium Everts to phosphine.

\section{F. Objectives of Work}

Given the situation above, this review work was carried out to bring to light the benefits associated with the use of LS produced from agricultural waste for food preservations and postharvest loss reduction. The rest of the work is put into sections that discuss Methodology used, the findings: an overview of LS, agricultural waste sources for producing LS, various application of LS in PHWL reduction, the systemic function of LS in food security and environmental conservation, then the conclusion.

\section{MATERIALS AND METHODS}

\section{A. Duration and Place of Work}

Most of the contributions and resources used for completing this work were largely obtained from Institut Pertanian Bogor (IPB University), Indonesia. The work lasted for a period of 6 months (January-June 2020).

\section{B. Gathering of Information}

Apart from the expert knowledge contributed directly by the authors, other major sources of information are: (i) personal communications and discussions, (ii) Library and internet sources. During the information gathering process, literature obtained from the various sources were checked 
by first reading the abstract, and if found relevant, a further reading of the other parts is continued. Bibliographies of searched materials also serve as a good stepping stone for searching for other relevant and related materials.

\section{Personal Communications and Discussions}

Experts such as lecturers and researchers who worked in the field of Postharvest technology, plant protection, and environmental science were consulted. This source of inputs was particularly relevant in building the conceptual framework (heart model) in this review article.

\section{Library and Internet Sources}

Offline library sources of literature were sourced from the IPB University library in Bogor, Indonesia. Online sources of literature came largely from, Google Scholar and Research gate. Supporting data from the websites of Food and Agricultural Organization (FAO), World Resources Institute (WRI), and the UN were also used.

Preferred articles included peer-reviewed articles, books, and research reports. The majority of the literature used were published in the English language with a handful being in the Indonesian language.

\section{Production of $L S$}

\section{RESULTS AND DISCUSSION}

LS can be described in simple terms as the condensed liquid products derived from the destructive distillation of woods or woody materials. While there may be some variation in the setup of the equipment for generating LS, the key tools necessary for successful generation are always the same for all setups. These include a regulated source of heat, chamber to hold the raw material or reactor, a connection pipe, a cooling chamber or condenser, and a collection vat (Figure 1). Some key factors of the set up to consider include: walls of the reactor must be designed to support anaerobic reaction within, the source of heat must be capable of being regulated and capacity to produce heat varying from $100{ }^{\circ} \mathrm{C}$ to $1000^{\circ} \mathrm{C}$ depending on the raw materials and the intended grade of the product. $[15,16]$ in their reports showed the setup of a LS generation unit installed with multiple filters and nitrogen gas sources connected to the reactor to regulate the gaseous composition. During the manufacturing process of the LS, the smoke generated from the pyrolysis of the raw material is condensed and collected as a solution. Pyrolysis is defined as the thermal breakdown of materials at higher temperatures in an inert atmosphere and normally involves a modification of the chemical constituents [17]. Most published reports about LS are unequivocal about the fact its antimicrobial properties, insecticidal properties, colour, and flavour of LS are determined by the temperature, moisture content of the wood and the kind of wood used to produce the smoke $[16,18]$. According to [19], the temperature used and conditions of processing contribute a greater variation between the condensates yielded than the differences between common wood types used. Other factors such as feed rate of particle size, vapour residence time, temperature, and oxygen infiltration can have substantial effects on the yield and composition of the LS. It is therefore appropriate that literary reports on LS compositions also include the process used and the conditions prevailing during the production.

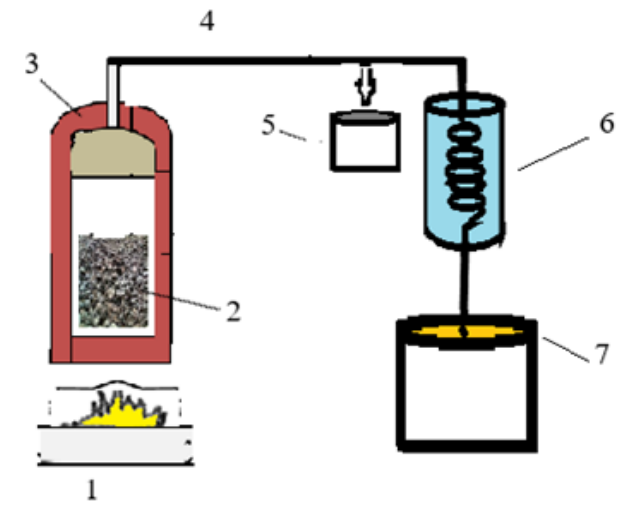

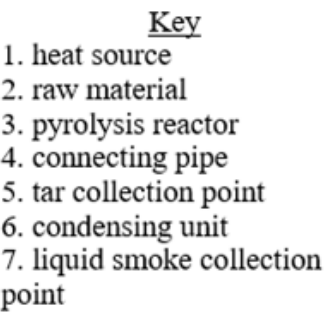

Fig. 1. Schematic diagram of the setup for LS production

\section{A. Components of $L S$}

Most wood and woody materials are made up of three major components: structures of cellulose, hemicellulose, and lignin. Cellulose is the first major component and makes up about 40 to $45 \%$ of the total dry weight of normal wood tis- sue. The second major component is hemicellulose which accounts for nearly $20-35 \%$ of the total dry mass of normal wood, the third key component of wood is lignin and can be found in amounts of 18-38\% [20]. Apart from the three major components, the remaining component of wood is 
generically referred to as resins. According to [21], resins typically contain stilbenes, terpenes, flavonoids lignans, and aromatic compounds that are often found in softwoods.

During the preparation of LS, pyrolysis of material occurs in a series of four stages: evaporation of remnant water from material, decomposition of the hemicelluloses, decomposition of cellulose, and finally decomposition of lignins. A report by [22] mentioned that evaporation of water from the raw material takes place at approximately $170^{\circ} \mathrm{C}$ with the concomitant production of acetic acid. The report also had it that decomposition of hemicellulose produces furans, furan derivatives, and a chain of aliphatic carboxylic acids. In other research works, the pyrolysis of cellulose and hemicellulose took place at $180-350^{\circ} \mathrm{C}$ and generated carboxylic acids and carbonyl compounds. lignins, on the other hand, get pyrolyzed at $300-500{ }^{\circ} \mathrm{C}$. This produced phenols and phenolic esters [21].

In addition to the main products of carbonyls, acids, and phenols, the pyrolysis process also generates undesirable compounds known as Polycyclic Aromatic Hydrocarbons (PAHs). Some of these PAHs, are naturally occurring, while others are produced as a result of incomplete combustion of the raw material. According to [19], the amount of PAHs formed is also dependent on the source of raw material.

\section{B. Agricultural Waste as Raw Material for LS}

The basic requirement that qualifies a material to be used for the production of LS is the possession of cellulose, hemicellulose, and lignin components. Thermal degradation of the material will generate a complex blend of compounds which will, in turn, characterize the organoleptic, antioxidative, antibacterial and insecticidal properties of the generated LS [22, 23].

In an attempt to reduce the negative environmental impact and better manage agricultural waste especially those resulting from postharvest activities, some of the organic waste materials and by-products from the food value chain have been utilized as raw materials for the production of LS. The approach has not only yielded environmental value but also economic and social value as well. Some of the main agricultural waste currently in use for the preparation of LS include empty coconut shell, coconut fibre, rice hull, rice husk, corn cob, corn husk, palm kernel shell, palm fronds, empty cocoa pod, cocoa bean skin, durian skin, tobacco stem, candle nutshell, etc (Table 2).

TABLE 2

AGRICULTURAL WASTE SOURCES OF RAW MATERIALS FOR PRODUCING LS IN RECENT YEARS

\begin{tabular}{ll}
\hline \hline Agricultural Waste Sources & References \\
\hline Coconut shell uses & {$[24],[25],[26],[27],[28],[29],[30],[31]$} \\
Coconut fibre & {$[29],[32]$} \\
Oil palm shell & {$[30],[31],[33],[34]$} \\
Empty Cocoa pod/shell & {$[35],[36],[37],[31]$} \\
Rice hull & {$[38],[39]$} \\
Rice husk & {$[28],[31],[40]$} \\
Corncob & {$[41]$} \\
Kenari (Canariun indicum L.) & {$[42]$} \\
Cocoa bean skin waste. & {$[25]$} \\
Palm kernel shell & {$[34],[43],[44]$} \\
Tobacco stem & {$[45]$} \\
Candle nutshell & {$[46]$} \\
Durian Skin & {$[30]$} \\
\hline \hline
\end{tabular}




\section{Grades and Uses oF LS in PHLW Reduction}

LS has gained multiple applications across diverse fields. Some of the uses include industrial raw materials and sources of energy. For instance, biochar produced from the pyrolysis of corncob is capable of being processed to become bio-briquettes (alternative solid fuel for homes and industries) or better still activated carbon which can serve as adsorbents for treatment of waste and water purification [47]. In addition to the uses motioned above, LS has also become popular in its use for food preservation and farm produce protection and the ultimate reduction of postharvest waste. LS is usually put into three grades based on its purity level and suitability for human consumption. Grade 1 is considered as the safest for direct human consumption. It is normally subjected to very high levels of purification to eliminate dangerous compounds like PAHs that could cause consumer poisoning. This makes it safe for direct treatment of meats and other products that are consumed directly. Grade 2 follows with a lower level of purification. Though may pass through some level of purification, direct consumption is not encouraged. Grade 3 LS is not recommended for direct consumption. It is also considered as the lowest quality of LS. Raw materials for production can be sourced from anywhere provided they meet the lignocellulosic composition standard. The higher the quality level of LS the better the chances of being used in food industries.

\section{Use as Biopesticides Against Insect Attack}

Research works to develop biopesticides advanced significantly only at the commencement of the twentieth century. These came about when concerns about negative environmental impacts, toxicity, residues, and insect resistance towards conventional pesticides begun rising [48]. When using LS as raw materials for insecticide, Grade 3 LS is often used [16].

[31] tested LS from coconut shells, cacao pod husks, sawdust, coconut shells, and rice husks against Coffee Berry Borers (CBB). All samples exhibited toxicity against CBB imagos. The highest mortality occurred from treatment with coconut shell LS at concentrations of $2.5 \%$. The report concluded that the major component in LS that functioned as insecticides is benzenesulfonic acid, 4-hydroxy, and acetic acid.

[33] observed that insects were repelled from LS treated dried fish even though LS was not lethal as conventional insecticides. This repellency property was attributed to the phenolic content of the LS.

[45] used LS of tobacco stem waste to control the larvae of Spodoptera litura under laboratory conditions. It was reported that the application of LS by using the spraying method (direct method) gave better results against the feeding/indirect method.

35 also tested LS generated from coconut fibre waste, they obtained $80 \%$ mortality of insects at a concentration of $10 \%$ against Estoloides sparse insects.

[40] experimented with various LS on soybean pod sucking insects (Nezara viridulla, Riptortus linearis, and Piezodorus hybneri). The results showed that the application of three types of LS could decrease the pest attack significantly. The percentage of pest attack on soybean plant with LS treatment was significantly lower as compared to that without LS treatment. The efficacy of the three types of LS was comparable to that of the commercial/synthetic pesticide used in the study.

\section{E. Use as Food Crop Protectant and Preservative}

Phenolic compounds in LS function by disturbing the membranes of the bacteria's cytoplasm leading to the leakage of the intracellular fluids. The efficacy of carbonyls as an antimicrobial can be attributed to the 133 different aldehydes and ketones present in LS [49]. [22] explained that carbonyls inhibit the growth of microbes by penetrating their cell walls and deactivating the enzymes positioned both inside the cytoplasm and the cytoplasmic membrane. LS can serve as a preservative because of its antimicrobial and antioxidant properties.

The microbial attack is responsible for the loss of $25-80 \%$ of most fresh produce before they get to the consumer. Recently, the available technologies used by fresh produce industries for reducing spoilage is progressively becoming sophisticated and complicated [50]. According to [51], commonly detected foodborne bacterial pathogens of fresh vegetables include Salmonella sp. coliform bacteria, Staphylococcus aureus, and Escherichia coli.

In an experiment conducted by [52], LS with concentrations $0.05-1 \%$ were evaluated against STEC strains of E. coli for their antimicrobial properties. Results showed a 1-day delay in microbe growth at $0.125 \%$ concentration, and at $0.25 \%$ concentration, zero growth was recorded. [53] reported very low Minimum Inhibitory Concentration (MIC) values for numerous commercial LS against E. coli 0157: H7. Effective concentrations were found to range from $6 \%$ to as low as $0.75 \%$ based on the commercial brand of LS. The same group investigated the MICs of some commercial LS samples against Salmonella typhimurium by using a microdilution technique. The LS samples were separated into 2 groups (groups 1 and 2) depending on the raw material used for their production. Group 2 LS was more effective at 
reducing Salmonella with MIC values ranging from $0.5 \%$ to $4 \%$.

Research and daily usage of LS for the preservation of horticultural crop are still limited compared to the other uses.

\section{F. For Preservation of Animal Food}

The usage of liquid for the preservation of animal food products is one of the widely known uses of LS. This is due to its antimicrobial, antioxidants, and flavouring properties. When subjecting LS to uses that involve direct contact with edible products, extra caution is taking to further purify the LS through processes like distillation to enhance food safety and protect the consumer. Hence Grade $1 \mathrm{LS}$ is used for such purposes.

20 reported that LS posed antimicrobial properties against a variety of Gram-positive and Gram-negative bacteria, moulds, and yeast. The most effective LS fraction with the highest antimicrobial activity had a low $\mathrm{pH}$ and high carbonyl content. The report concluded that phenols did not significantly influence the antimicrobial properties of LS. According to [17], LS is frequently used for preserving protein-based foods like cheese, meat, fish due to the pleasant flavour it leaves in food, besides, it also inhibits the proliferation of foodborne pathogens. The use of LS for preserving fish and meat have numerous advantages over conventional smoking techniques. Some of the advantages include the simplicity of the application process, a faster rate of the smoking process, replicability of desirable features smoked food, and elimination of dangerous PAH's [17].

[36] recommended that redistilled LS produced from oilpalm shells can serve as a good fish preservative and can also be combined with other preservation methods like salting and cooling. The effects of LS on E. coli in a model meat system was reported by [54], beef trimmings were inoculated with $7 \log 10 \mathrm{CFU} / \mathrm{g}$ of the STEC strain E. coli 0157: H7 and treated with a final concentration of $8 \%$ LS fraction, LS treated trim potions exhibited a $2.3 \log 10 \mathrm{CFU} / \mathrm{g}$ decrease after 3 days of chilled storage.

\section{G. Impact of Food Waste on Environment}

Data from [55] shows that globally, the total food that ends up in the garbage rather than the plate comes as the thirdlargest emitter of Greenhouse Gases (GHG), just behind China and the US.

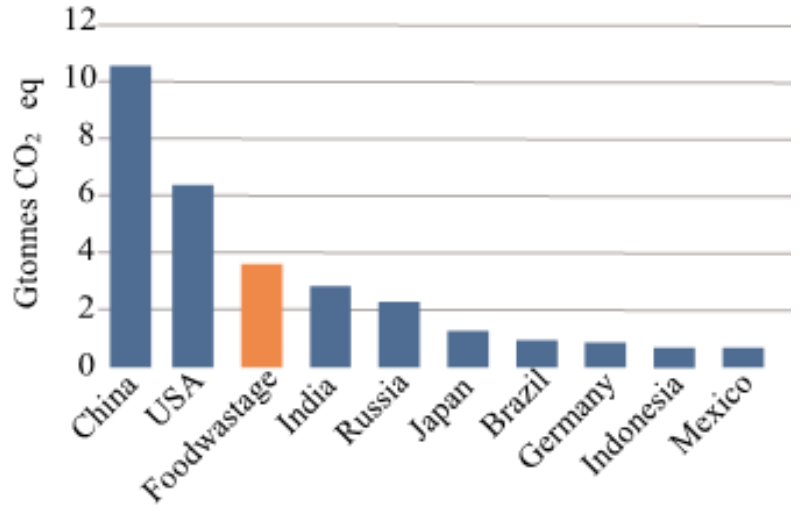

Fig. 2. The position of food waste as a contributor to GHG emission [56]

\section{H. Systemic Function of LS in Food Security and Envi- ronmental Conservation}

According to the [57] interventions put in place to reduce PHLW should not be designed to just achieve a single targeted goal but should also lead to the achievement of other socio-environmental goals and help promote sustainable food systems. Figure 3 is a conceptual framework that shows the interdependent system effects created when LS produced from postharvest waste is used to manage postharvest losses. The diagram portrays the system directly contributes to the achievement of SDG goal number 12.5 whiles goals number $1.5,2.6,11.6$, and 13 are also addressed indirectly [1].

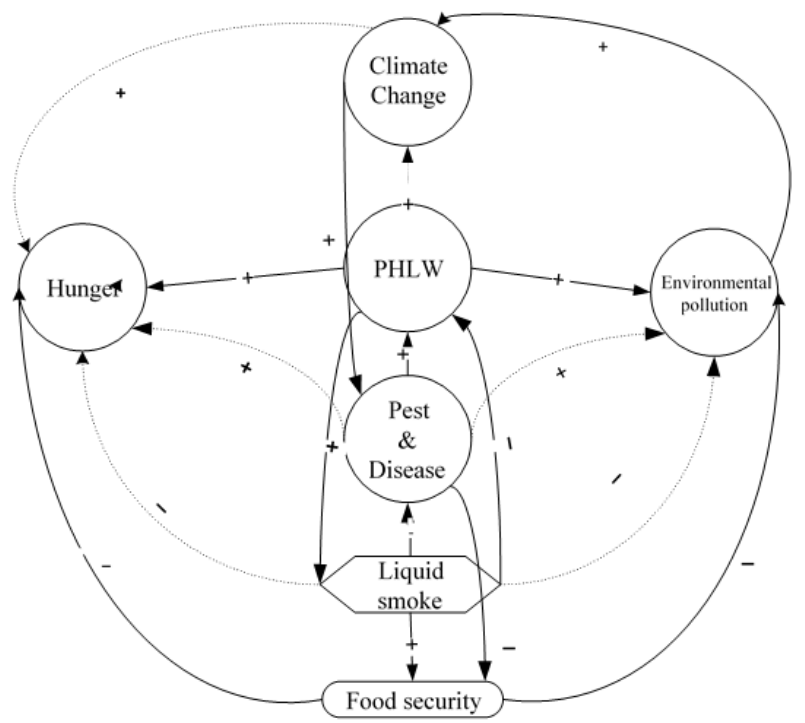

Fig. 3. Conceptual framework (heart model) showing the benefits derived from using LS for reducing PHLW (solid lines represent strong direct effect while the broken lines represent indirect effects. The positive and negative signs indicate increasing and decreasing effects on the direction of the arrow) 
The loops in the framework above depict the self-sustaining system created when waste from agricultural products is managed well and used in the form of LS to reduce PHLW. Since PHLW directly increases environmental pollution, climate change, and hunger LS as a PHLW reduction method automatically reduce the magnitude of this problem too [58]. Besides, the sourcing of raw materials for LS from the agricultural waste materials reduces the volume of waste material that could have been discarded improperly thereby causing environmental pollution and greenhouse gases leading to climate change. On other extended effects, forest destroyed during land preparation, water and fertilizers (manure \& synthetic) expended during production all together contributes remotely to environmental pollution and climate change. About 1.4 billion hectares, $(30 \%$ of fertile land globally) are used in producing food that either gets lost or wasted [8].

Climate change on its own is also a threat to food security. It often creates extreme weather which is unfavourable for the production and storage of food. Under such extreme conditions, farms get flooded or too dried, the yield is greatly reduced, diseases and pests are rampant and storage becomes a problem because of continuous rain that allows for proper drying of excessive heat from the sun which hastens the physiological activities of horticultural products $[59,60]$. Pest and disease also occupy a significant place in the PHLW system. It creates a ripple effect that increases losses and reduces food security. Conversion of waste into a solution for managing PHLW, therefore, creates a self-sustaining system for the achievement of food security.

\section{CONCLUSION}

Factors identified to be responsible for postharvest losses of crops have been categorized into groups of physiological, mechanical, biological, and microbiological, chemical, and biochemical factors. Concerns about consumer health, negative environmental impacts, toxicity, residues, and insect resistance towards conventional chemical pesticides led to the research of natural and sustainable alternatives like LS. LS possesses antimicrobial, antioxidant, and insecticidal properties due to its lignocellulosic composition. Another reason that makes LS a more sustainable option among other close options is its cheap sources of raw materials such as agricultural waste which in turn reliefs the environment of pollution. Sustainable PHLW reduction strategies often leave positive externalities on the environment and other areas. This happens by the reduction of waste on landfills, indirect reduction of food prices, and the ultimate reduction in negative environmental impacts resulting from the cultivation of forest land. These properties among others have made LS an all-round ingredient to be used for food preservation and reduction of postharvest losses.

\section{REFERENCES}

[1] United Nations, "Transforming our world: The 2030 agenda for sustainable development," 2015. [Online]. Available: https://bit.ly/20ig1Rq

[2] J. Parfitt, M. Barthel, and S. Macnaughton, "Food waste within food supply chains: Quantification and potential for change to 2050," Philosophical Transactions of the Royal Society B: Biological Sciences, vol. 365, no. 1554, pp. 3065-3081, 2010. doi: https://doi.org/10.1098/rstb.2010.0126

[3] S. Noura, K. Mohamed, A. Mohammed, and B. Annick, "Extraction of residual sugars from sweet pearl millet and sweet sorghum bagasse for an eventual production of bioethanol," International Journal of Applied and Physical Sciences, vol. 1, no. 1, pp. 14-18, 2015. doi: https://doi.org/10.20469/ijaps.50002

[4] E. M. Yahia, Postharvest Technology of Perishable Horticultural Commodities. London, UK: Woodhead Publishing, 2019.

[5] Food and Agriculture Organization, "Definitional working paper framework of food loss home," 2014. [Online]. Available: https://bit.ly/3emv5Ic

[6] Food and Agriculture Organization, "Food loss prevention in perishable crops," 1981. [Online]. Available: https://bit.ly/3iW6GNq

[7] A. B. Abass, G. Ndunguru, P. Mamiro, B. Alenkhe, N. Mlingi, and M. Bekunda, "Post-harvest food losses in a maize-based farming system of semi-arid savannah area of Tanzania," Journal of Stored Products Research, vol. 57, pp. 49-57, 2014. doi: https://doi.org/10.1016/j.jspr.2013.12.004

[8] Food and Agriculture Organization, "Global food losses and food waste-extent, causes and prevention," 2011. [Online]. Available: https://bit.ly/2APD4jq

[9] H. Ritchie, D. S. Reay, and P. Higgins, "Beyond calories: A holistic assessment of the global food system," Frontiers in Sustainable Food Systems, vol. 2, pp. 57-65, 2018. doi: https://doi.org/10.3389/fsufs.2018.00057 
[10] V. Castro, A. Tambasco, L. Paraíba, and D. Tambasco, "Cytogenetic and teratological effects of mancozeb pre natal exposure on rats," Brazilian Archives of Biology and Technology, vol. 42, no. 2, pp. 20-40, 1999. doi: https://doi.org/ 10.1590/s1516-89131999000200001

[11] W. Jeong, M. Kim, J. Park, and J. H. Roh, "Relation between air pollutants emissions and bess capacity operated for maximizing customer's profit," Journal of Applied and Physical Sciences, vol. 2, no. 2, pp. 54-64, 2016. doi: https://doi. org/10.20474/japs-2.2.5

[12] K. Osman, A. Al-Humaid, S. Al-Rehiayani, and K. Al-Redhaiman, "Monitoring of pesticide residues in vegetables marketed in Al-Qassim region, Saudi Arabia," Ecotoxicology and Environmental Safety, vol. 73, no. 6, pp. 1433-1439, 2010. doi: https://doi.org/10.1007/s10661-006-1493-7

[13] D. G. Alston, "The Integrated Pest Management (IPM) concept," 2011. [Online]. Available: https://bit.ly/3iUlQm6

[14] Ö. Sağlam, P. A. Edde, and T. W. Phillips, "Resistance of lasioderma serricorne (Coleoptera: Anobiidae) to fumigation with phosphine," Journal of Economic Entomology, vol. 108, no. 5, pp. 2489-2495, 2015. doi: https://doi.org/10.1093/ jee/tov193

[15] J. M. Lingbeck, P. Cordero, C. A. O'Bryan, M. G. Johnson, S. C. Ricke, and P. G. Crandall, "Functionality of liquid smoke as an all-natural antimicrobial in food preservation," Meat Science, vol. 97, no. 2, pp. 197-206, 2014. doi: https://doi.org/ 10.1016/j.meatsci.2014.02.003

[16] A. Aladin, S. Yani, B. Modding, and L. Wiyani, "Pyrolisis of corncob waste to produce liquid smoke," in IOP Conference Series: Earth and Environmental Science, London, UK, 2018.

[17] J. Alemán, A. V. Chadwick, J. He, M. Hess, K. Horie, R. G. Jones, P. Kratochvíl, I. Meisel, I. Mita, G. Moad et al., “Definitions of terms relating to the structure and processing of sols, gels, networks, and inorganic-organic hybrid materials (IUPAC recommendations 2007),"' Pure and Applied Chemistry, vol. 79, no. 10, pp. 1801-1829, 2007. doi: https://doi.org/10. 1351/pac200779101801

[18] S. Soldera, N. Sebastianutto, and R. Bortolomeazzi, "Composition of phenolic compounds and antioxidant activity of commercial aqueous smoke flavorings," Journal of Agricultural and Food Chemistry, vol. 56, no. 8, pp. 2727-2734, 2008. doi: https://doi.org/10.1021/jf072117d

[19] M. D. Guillén, P. Sopelana, and M. A. Partearroyo, "Polycyclic aromatic hydrocarbons in liquid smoke flavorings obtained from different types of wood: Effect of storage in polyethylene flasks on their concentrations," Journal of Agricultural and Food Chemistry, vol. 48, no. 10, pp. 5083-5087, 2000.

[20] J. Maga, Potential Health Concerns Associated with Smoke. Boca Raton, FL: CRC Press Inc, 1988.

[21] M. Asmadi, H. Kawamoto, and S. Saka, "Gas-and solid/liquid-phase reactions during pyrolysis of softwood and hardwood lignins," Journal of Analytical and Applied Pyrolysis, vol. 92, no. 2, pp. 417-425, 2011. doi: https://doi.org/10. 1016/j.jaap.2011.08.003

[22] P. J. Milly, R. T. Toledo, and S. Ramakrishnan, "Determination of minimum inhibitory concentrations of liquid smoke fractions," Journal of Food Science, vol. 70, no. 1, pp. 12-17, 2005. doi: https://doi.org/10.1111/j.1365-2621.2005. tb09040.x

[23] Q. Wei, X. Ma, and J. Dong, "Preparation, chemical constituents and antimicrobial activity of pyroligneous acids from walnut tree branches," Journal of Analytical and Applied Pyrolysis, vol. 87, no. 1, pp. 24-28, 2010. doi: https://doi.org/ 10.1016/j.jaap.2009.09.006

[24] S. Kailaku, M. Syakir, I. Mulyawanti, and A. Syah, "Antimicrobial activity of coconut shell liquid smoke," in IOP Conference of Seramic and Material Science and Engineering, New York, NY, 2017.

[25] L. Handojo, Cherilisa, and A. Indarto, "Cocoa bean skin waste as potential raw material for liquid smoke production," Environmental Technology, vol. 41, no. 8, pp. 1044-1053, 2020. doi: https://doi.org/10.1080/09593330.2018. 1520306

[26] M. Muslimin, K. Kamil, S. A. S. Budi, and I. Wardana, "Effect of liquid smoke on surface morphology and tensile strength of Sago Fiber," Journal of Mechanical Engineering and Sciences, vol. 13, no. 4, pp. 6165-6177, 2019. doi: https://doi. org/10.15282/jmes.13.4.2019.27.0483

[27] R. Hadanu and D. A. N. Apituley, "Volatile compounds detected in coconut shell liquid smoke through pyrolysis at a fractioning temperature of 350-420 ${ }^{\circ}$ C," Makara Journal of Science, vol. 20, no. 3, pp. 1-15, 2016. doi: https://doi.org/ $10.7454 /$ mss.v20i3.6239 
[28] I. Mulyawanti, S. Kailaku, A. Syah et al., "Chemical identification of coconut shell liquid smoke," in IOP Conference Series: Earth and Environmental Science, New York, NY, 2019.

[29] K. Budaraga, Y. Marlida, U. Bulanin et al., "Liquid smoke production quality from raw materials variation and different pyrolysis temperature," International Journal on Advanced Science, Engineering and Information Technology, vol. 6, no. 3, pp. 306-315, 2016. doi: https://doi.org/10.18517/ijaseit.6.3.737

[30] R. M. Sari, S. Gea, B. Wirjosentono, and S. Hendrana, "Quality improvement of liquid smoke of coconut shell by tar scrubber," in Proceedings of the 1st International Conference on Chemical Science and Technology Innovation, California, CA, 2019.

[31] G. Indriati and S. Samsudin, "Potential of liquid smoke as botanical insecticide to control coffee berry borer hypothenemus hampei," Jurnal Tanaman Industri dan Penyegar, vol. 5, no. 3, pp. 123-134, 2018. doi: https://doi.org/10.21082/ jtidp.v5n3.2018.p123-134

[32] I. D. K. Anom and J. J. Mamangkey, "Utilization of coconut fiber waste as insecticides against epilachna sparsa," 2016. [Online]. Available: https://bit.ly/2ZobhjL

[33] S. Achmadi, N. Mubarik, R. Nursyamsi, and P. Septiaji, "Characterization of redistilled liquid smoke of oil-palm shells and its application as fish preservatives," Journal of Applied Sciences, vol. 13, no. 3, pp. 401-408, 2013. doi: https://doi. org/10.3923/jas.2013.401.408

[34] A. Gani, H. Husni, A. Baihaqi, and M. Faisal, "Potential development of liquid smoke from oil palm solid waste as biofungicides," International Journal of Science and Engineering, vol. 7, no. 1, pp. 65-69, 2014. doi: https://doi.org/10. 12777/ijse.7.1.65-69

[35] I. K. Budaraga, E. Susanti, A. Asnurita, E. Nurdin, and R. Ramaiyulis, "The antioxidant characteristics of the liquid smoke of cocoa shell (Theobroma cacao, l) in different water content variations," Journal of Applied Agricultural Science and Technology, vol. 3, no. 2, pp. 226-238, 2019. doi: https://doi.org/10.32530/jaast.v3i2.106

[36] R. Putri, A. Kasim, A. Asben et al., "Pyrolysis and characterization of liquid smoke from cacao pod husks," in IOP Conference Series: Earth and Environmental Science, California, CA, 2019.

[37] E. Ameko, S. Achio, F. Kutsanedzie, A. Abrokwah, D. Laar, and J. T. A. P. Goddey, "Conversion of three types of waste biomass in ghana (coconut shell, coconut husk and mahogany) into liquid smokes and determination of the sensory profiles," International Journal of Engineering and Resolution Technology, vol. 3, no. 12, pp. 1107-1114, 2014.

[38] S. P. Kim, M. Y. Kang, J. C. Park, S. H. Nam, and M. Friedman, "Rice hull smoke extract inactivates salmonella typhimurium in laboratory media and protects infected mice against mortality," Journal of Food Science, vol. 77, no. 1, pp. 80-85, 2012. doi: https://doi.org/10.1111/j.1750-3841.2011.02478.x.

[39] S. P. Kim, J. Y. Yang, M. Y. Kang, J. C. Park, S. H. Nam, and M. Friedman, “Composition of liquid rice hull smoke and anti-inflammatory effects in mice," Journal of Agricultural and Food Chemistry, vol. 59, no. 9, pp. 4570-4581, 2011. doi: https://doi.org/10.1021/jf2003392

[40] R. Risfaheri, H. Hoerudin, and M. Syakir, "Utilization of rice husk for production of multifunctional liquid smoke," Journal of Advanced Agricultural Technologies Vol, vol. 5, no. 3, pp. 192-197, 2018. doi: https://doi.org/10.18178/joaat.5. 3.192-197

[41] T. Handayani, D. Xyzquolyna, Y. Pranoto, and A. Suratman, "Reduction of pb (ii) ion in soybean seeds (glycine max) using corncob liquid smoke," in IOP Conference Series: Earth and Environmental Science, London, UK, 2009.

[42] Y. Yusnaini, S. Soeparno, E. Suryanto, and R. Armunanto, "Physical, chemical and sensory properties of kenari (Canariun indicum L.) shell liquid smoke-immersed-beef on different level of dilution," Journal of the Indonesian Tropical Animal Agriculture, vol. 37, no. 1, pp. 27-33, 2012. doi: https://doi.org/10.14710/jitaa.37.1.27-33

[43] M. Lasindrang, "Potential of liquid smoke from palm kernel shell as biopreservative to Tuna (Thunnus sp) fish protein," Indonesian Food and Nutrition Progress, vol. 14, no. 1, pp. 59-67, 2017. doi: https://doi.org/10.22146/ifnp.24281

[44] L. Nimah, M. F. Setiawan, and S. P. Prabowo, "Utilization of waste palm kernel shells and empty palm oil bunches as raw material production of liquid smoke," in IOP Conference Series: Earth and Environmental Science, Bangkok, Thailand, 2019.

[45] H. Prabowo, E. Martono, and W. Witjaksono, "Activity of liquid smoke of tobacco stem waste as an insecticide on spodoptera litura fabricius larvae," Jurnal Perlindungan Tanaman Indonesia, vol. 20, no. 1, pp. 22-27, 2016. doi: https://doi.org/10.22146/jpti.16620 
[46] R. H. Sulhatun and H. Harahap, "'improving production of liquid smoke from candlenut shell by pyrolisis process," Journal of Micoms, vol. 5, no. 6, pp. 143-149, 2017.

[47] D. A. Laird, R. C. Brown, J. E. Amonette, and J. Lehmann, “Review of the pyrolysis platform for coproducing bio-oil and biochar," Biofuels, Bioproducts and Biorefining, vol. 3, no. 5, pp. 547-562, 2009. doi: https://doi.org/10.1002/bbb.169

[48] J. J. Villaverde, P. Sandín-España, B. Sevilla-Morán, C. López-Goti, and J. L. Alonso-Prados, "Biopesticides from natural products: Current development, legislative framework, and future trends," Bio Resources, vol. 11, no. 2, pp. 5618-5640, 2016. doi: https://doi.org/10.15376/biores.11.2.villaverde

[49] N. Montazeri, A. C. Oliveira, B. H. Himelbloom, M. B. Leigh, and C. A. Crapo, "Chemical characterization of commercial liquid smoke products," Food Science \& Nutrition, vol. 1, no. 1, pp. 102-115, 2013. doi: https://doi.org/10.1002/fsn3.9

[50] B. Niemira, C. Sommers, and D. Ukuku, Mechanisms of Microbial Spoilage of Fruits and Vegetables. New York, NY: CRC Press, 2005.

[51] V. Tournas, "Moulds and yeasts in fresh and minimally processed vegetables, and sprouts," International Journal of Food Microbiology, vol. 99, no. 1, pp. 71-77, 2005. doi: https://doi.org/10.1016/j.ijfoodmicro.2004.08.009

[52] K. Fretheim, P. Granum, and E. Vold, "Influence of generation temperature on the chemical composition, antioxidative, and antimicrobial effects of wood smoke," Journal of Food Science, vol. 45, no. 4, pp. 999-1002, 1980. doi: https://doi. org/10.1111/j.1365-2621.1980.tb07497.x

[53] E. J. Van Loo, D. Babu, P. G. Crandall, and S. C. Ricke, "Screening of commercial and pecan shell extracted liquid smoke agents as natural antimicrobials against foodborne pathogens," Journal of Food Protection, vol. 75, no. 6, pp. 1148-1152, 2012. doi: https://doi.org/10.4315/0362-028x.jfp-11-543

[54] R. Estrada-Muñoz, E. Boyle, and J. Marsden, "Liquid smoke effects on escherichia coli o157: H7, and its antioxidant properties in beef products," Journal of Food Science, vol. 63, no. 1, pp. 150-153, 1998. doi: https://doi.org/10.1111/ j.1365-2621.1998.tb15697.x

[55] World Resources Institute, "CAIT-country greenhouse gas emissions data," 2012. [Online]. Available: https: //bit.ly/3022e75

[56] Food and Agroculture Organization, "Food wastage footprint," 2015. [Online]. Available: https://bit.ly/2APaMFI

[57] Food and Agriculture Organization, "State of food and agriculture in Asia and the Pacific Region, including future prospects and emerging issues," 2018. [Online]. Available: https://bit.ly/2WcR8Lp

[58] Food and Agriculture Organization of the United Nations, "Save food: Global initiative on food loss and waste reduction," 2018. [Online]. Available: https://bit.ly/20k4Gk0

[59] Intergovernmental Panel on Climate Change, "IPCC expert meeting on climate change, food, and agriculture," 2015. [Online]. Available: https://bit.ly/3gX8Jix

[60] Food and Agriculture Organization, "Food security and climate change: A report by the high level panel of experts on food security and nutrition," 2012. [Online]. Available: https://bit.ly/3298759 